Розділ І. Ціннісні орієнтири духовно-інтелектуального виховання, розвиток духовно-інтелектуальних якостей особистості в умовах співпраці й інклюзії

\title{
МОРАЛЬНО-ЕСТЕТИЧНЕ ВИХОВАННЯ УЧНІВ ПОЧАТКОВОЇ ШКОЛИ НА УРОКАХ МИСТЕЦТВА
}

\section{Мойсеснко Р. М.}

кандидат педагогічних наук, доцент, доцент кафедри педагогіки та освіти, Маріупольський державний університет, м. Маріуполь, Україна

У статті висвітлено проблему формування морального та естетичного виховання учнів початкової школи; визначено педагогічні умови, щуо сприяють формуванню моральності та естетичних смаків учнів; наголошено на необхідності використання на уроках мистецттва найкращих зразків народної та класичної музики, творів інших видів мистецтв як засобів морального та естетичного розвитку молодших школярів.

Ключові слова: виховання, морально-естетичне виховання, музичне мистеитво, зміст навчального матеріалу.

The article highlights the problem of formation of moral and aesthetic education of primary school students; identifies pedagogical conditions that contribute to the formation of morality and aesthetic tastes of students; emphasis is placed on the need to use the best examples of folk and classical music, works of other arts as the means of moral and aesthetic development of primary school students during the art lessons.

Key words: education, moral and aesthetic education, musical art, content of educational material.

Одним із пріоритетних завдань сучасної початкової школи є виховання духовної, моральної особистості, яка розуміє доброту, повагу до людей, милосердя як необхідну рису людини та здатна сприймати красу навколишнього світу в усіх її проявах.

Загальні тенденції морального та естетичного виховання молоді висвітлено у нормативних документах про освіту: Законах України «Про загальну середню освіту», «Про освіту», «Про культуру», «Про основні орієнтири виховання учнів 1-11-х класів загальноосвітніх шкіл України» та інших, які визначили провідні напрями морально-духовного удосконалення особистості. Зокрема, у Концепції «Нова Українська школа» наголошено на тому, що виховний процес, як складова освітнього процесу, буде орієнтуватися на загальнолюдські цінності, моральні норми, надбання культурної спадщини людства [4]. 
Виховання, як процес підготовки підростаючого покоління до життя, явище багатогранне, однак серед багатьох його складових моральне та естетичне виховання складають підгрунтя вихованості, духовності особистості, яка прагне жити за законами краси та їх не можна відокремити у якийсь спеціальний виховний процес.

У різні часи ідею морального виховання молоді на основі фольклору відстоювали видатні педагоги, поети, прогресивні діячі освіти та мистецтва: Г. Сковорода, Б. Грінченко, М. Драгоманов, О. Духнович, М. Леонтович, Л. Українка, І. Франко, К. Ушинський.

Теоретично обгрунтував специфіку морального виховання учнів, його завдання і цілі Г. Сковорода. Він наголошував на тому, що «цінувати людину треба за їі внутрішню красу, за іiі розум і моральні якості», вказував на зв'язок морального виховання з життям народу, його традиціями [3]. У своїй виховній практиці він використовував широкий арсенал засобів, у тому числі й народні пісні, притчі, високо цінуючи народну творчість та відзначаючи ії виховне значення для кожної людини.

Ідеї морального виховання знайшли відображення у працях сучасних українських вчених: І. Беха, О. Вишневського, О. Савченко, О. Сухомлинської, М. Чепіль. Видатний педагог та вчений І. Зязюн зазначав, що «ідеал українського національного виховання — це гармонійно і всебічно розвинена особистість українця з інтелектуально-творчими, духовно-моральними цінностями» [2].

У наукових розвідках вчених В. Лозової та Г. Троцко моральне виховання особистості визначається як «цілеспрямований процес організації та стимулювання різнобічної діяльності учнів, їх спілкування, що спрямований на оволодіння школярами моральною культурою, яка визначає ставлення до навколишнього світу» [5]. Моральне виховання дуже тісно пов'язане з естетичним вихованням та його різновидами (музичним, образотворчим).

3 давнини музичне виховання вважалося одним із найважливіших чинників формування духовної культури особистості. Значний внесок у дослідження проблем музично-естетичного виховання в загальнопедагогічному аспекті зробили: Л. Аристова, Д. Кабалевський, О. Калініченко, О. Лобова, Л. Масол, Г. Падалка, О. Рудницька, О. Цокур та інші.

Успішне вирішення завдань естетичного розвитку учнів залежить від вдосконалення змісту навчального матеріалу, який закладено у про- 
Розділ І. Ціннісні орієнтири духовно-інтелектуального виховання, розвиток духовно-інтелектуальних якостей особистості в умовах співпраці й інклюзії

грами інтегрованого курсу «Мистецтво» у 1-4 класах початкової школи. Аналіз теоретичної та методичної бази підручників з мистецтва дозволяє стверджувати, що їх автори (Л. Аристова, Л. Кондратова, Н. Лємєшева, Л. Масол, Т. Рубля) гармонійно поєднали надбання культури людства, кращих музичних творів класичної та народної музики, хорових та інструментальних жанрів, українських народних пісень у тісному взаємозв'язку з літературою та образотворчим мистецтвом. Слід зазначити, що у підручниках зосереджена значна увага на значущості сучасного пісенного репертуару для дітей та особливості його використання на уроці музичного мистецтва. Твори різних видів мистецтва покликані не тільки зацікавити учнів, а стати ефективним засобом виховання, сприяти розвитку усвідомлення учнями початкових класів загальнолюдських моральних цінностей, мелодійності та чарівності мови звуків та рідної мови.

Під морально-естетичним вихованням ми розуміємо процес, що охоплює особистісні передумови до прийняття моральних норм, морального прикладу, в процесі залучення учнів до активної творчої діяльності з використанням специфічних засобів виразності різних видів мистецтв: літератури, музики, живопису та народної творчості.

Безумовно, вчителеві необхідно широко використовувати на уроці як сучасні твори, так і різні види фольклору, знайомлячи учнів з багатством народної творчості, народної мудрості, різноплановістю народної пісні, приспівок, тим самим залучаючи їх до розуміння моральних загальнолюдських цінностей, що закладені у змісті пісень. Наприклад, у народних піснях («Грицю, Грицю, до роботи», «Ой на горі жито», «По дорозі жук») влучно оцінюються різні життєві позиції, висміюються недоліки, вихваляються позитивні якості людей. Пробуджують в учнів відчуття симпатії, формують світоглядні уявлення про добро, повагу до людей, членів родини, до всього живого українські народні пісні «Ходить гарбуз по городу», «Зацвіла в долині» та сучасні пісні для дітей «Моя сім'я», «Бабуся», «Мамин день» [6].

На основі теоретичного аналізу наукових джерел можна визначити педагогічні умови, що сприяють формуванню моральності та естетичних смаків учнів: цілеспрямованість уроку щодо моральноестетичного виховання; правильний відбір художнього матеріалу та відповідних йому методів та прийомів навчання; спеціальна спрямованість роботи вчителя на уроці музичного мистецтва, що передбачає 
формування естетичних смаків молодших школярів; створення необхідної психологічної атмосфери протягом всього уроку; активізація почуттів і переживань естетичного характеру в момент сприйняття твору мистецтва; естетична освіченість та методична підготовленість самого вчителя до уроку мистецтва; врахування впливу естетичних інтересів та естетичних смаків дорослих на дітей, впливу засобів масової інформації на розвиток естетичних почуттів, формування естетичних смаків та моральності учнів.

Отже, на уроках музичного мистецтва відбувається взаємозв'язок і взаємовплив не тільки різних видів мистецтв, а й виховуються духовність, моральність, все те, що пов'язане з внутрішнім світом дитини, iii настроями, переживаннями, почуттями. Тому формування морально та естетично розвиненої особистості учнів початкової школи на уроці музичного мистецтва доцільно здійснювати у процесі комплексного сприйняття мистецтв.

\section{Список використаних джерел:}

1. Григор'єва О.М. Психолого-педагогічні умови розвитку музично-естетичного смаку молодших школярів. Музичне і театральне мистецтва: проблеми викладання. 2006. № 2. С. 12-15.

2. Зязюн I. А. Педагогічна майстерність як мистецька дія : посібник для вчителів. Київ: Вища школа, 1997. 349 с.

3. Кольцова O.C. Моральне виховання в історії педагогічної науки. URL: https://www.sportpedagogy.org.ua/html/journal/2008-11/08koshps.pdf. (Дата звернення: 10.10.2021).

4. Концепція «Нова українська школа». URL: https://www.kmu.gov.ua/... / ukrainska-shkola-compressed.pd... (Дата звернення 10.10.2021).

5. Лозова В.І., Троцько Г.В. Теоретичні основи виховання і навчання : навч. посіб. Харків : «ОВС», 2002. 400 с.

6. Оновлені програми для основної школи освітньої галузі «Мистецтво» (2017- 2018 н.p.). URL: https://artmon59-new.edera.com/ (Дата звернення: 09.10.2021) 